\title{
Optimalisasi Dakwah Media Sosial di Kalangan Mahasiswa di Masa Pandemi Dalam Dimensi Globalisasi
}

\author{
Mohammad Rindu Fajar Islamy \\ Universitas Pendidikan Indonesia \\ Fajaislam2000@upi.edu
}

\begin{abstract}
This study aims to measure the optimization of social media preaching among students in the dimensions of globalization during the Covid-19 pandemic. The contemporary da'wah movement is currently giving birth to new styles and models as a result of the response to the transformation of cultural civilizations of the global community as a result of globalization. Globalization affects most of the fundamental aspects of modern society, including economy, politics, culture, education, and da'wah activities. Students are agents of change in the future, there needs to be serious efforts from education practitioners in order to direct them to be more active in increasing their spirituality and individual piety through online Islamic da'wah studies. The research method uses a quantitative approach with questionnaire techniques, amounting to 10 question instruments distributed via google form. The data collection used a random sampling technique in which 36 respondents were taken from several students at one of the universities in Bandung. The results showed that most of the time distributed by students on social media had a negative tendency which was not productive compared to positive activities.
\end{abstract}

Keywords: Optimization, Da'wah, Social Media, Students, Globalization, Online

\begin{abstract}
Abstrak
Penelitian ini bertujuan untuk mengukur optimalisasi dakwah media sosial dikalangan mahasiswa dalam dimensi globalisasi pada masa pandemi Covid-19. Gerakan dakwah kontemporer saat ini melahirkan corak dan model baru sebagai akibat respon adanya transformasi peradaban kultur dan budaya masyarakat global dampak dari arus globalisasi. Globalisasi mempengaruhi Sebagian besar aspek-aspek fundamental dalam kehidupan masyarakat modern diantaranya ekonomi, politik, budaya, pendidikan, hingga aktivias dakwah. Mahasiswa merupakan agen perubahan dimasa
\end{abstract}


$2 \mid \mathrm{Jurnal}$ Dakwah dan Komunikasi, Vol.6 No.1, 2021

depan, perlu adanya upaya-upaya serius dari para praktisi pendidikan dalam rangka bagaimana mengarahkan mereka agar lebih aktif untuk meningkatkan spiritualitas dan kesalehan individu mereka melalui kajian dakwah islam secara online. Metode penelitian menggunakan pendekatan kuantitatif dengan teknik quisioner yang berjumlah 10 instrumen pertanyaan yang disebar melalui google form. Adapun pengumpulan data menggunakan teknik random sampling dimana responden berjumlah 36 orang diambil dari beberapa mahasiswa di salah satu perguruan tinggi di Bandung. Hasil penelitian menunjukkan bahwa Sebagian besar waktu yang didistribusikan oleh mahasiswa pada media sosial memiliki kecenderungan negative yang tidak produktif dibandingkan dengan aktifitas positif.

Kata kunci: Optimalisasi, Dakwah, Media Sosial, Mahasiswa, Globalisasi, Online.

\section{Pendahuluan}

Kemunculan virus Covid-19 pada akhir tahun 2019 membuat dunia internasional membunyikan alarm tanda bahaya yang akan menyerang. Para ahli dari bidang kedokteran menyatakan bahwa virus ini Sebagian besar menyerang system pernafasan 1. Mengutip dari Satgas Covid-19 melalui laman websitenya, jumlah penduduk Indonesia yang dinyatakan positif pertanggal 23 Februari 2021 sebanyak 1.298.608 orang. ${ }^{2}$ Dampak yang ditimbulkan oleh pandemic Covid dirasakan hampir diseluruh sektor terutama ekonomi, politik, pariwisata, pembangunan, pendidikan, hingga Kesehatan ${ }^{3}$. Problematika lain yang dihadapi masyarakat global saat ini bersamaan dengan kehadiran Covid-19 yaitu arus globalisasi. Para intelektual, cendekiawan, pemerintah begitu cemas dalam beradaptasi menghadapi Covid-19 dan globalisasi secara bersamaan. Globalisasi begitu terasa dampaknya secara signifikan terhadap perubahan kultur, budaya, ekonomi, politik, bahkan dunia

${ }^{1}$ Fabrizio Albarello et al., "2019-Novel Coronavirus Severe Adult Respiratory Distress Syndrome in Two Cases in Italy: An Uncommon Radiological Presentation," International Journal of Infectious Diseases 93 (2020): 192-197.

2 https:// covid19.go.id/

3 Asep Suryahadi, Ridho Al Izzati, and Daniel Suryadarma, "Estimating the Impact of Covid-19 on Poverty in Indonesia," Bulletin of Indonesian Economic Studies 56, no. 2 (2020): 175-192; Abdul Abiad et al., "The Economic Impact of the COVID-19 Outbreak on Developing Asia," ADB Briefs 3, no. 128 (2020): 1-13, http://dx.doi.org/10.22617/BRF200096; Albarello et al., "2019-Novel Coronavirus Severe Adult Respiratory Distress Syndrome in Two Cases in Italy: An Uncommon Radiological Presentation”; Qianying Lin et al., “A Conceptual Model for the Coronavirus Disease 2019 (COVID-19) Outbreak in Wuhan, China with Individual Reaction and Governmental Action," International Journal of Infectious Diseases 93 (2020): 211-216, https://doi.org/10.1016/j.ijid.2020.02.058. 
pendidikan tidak terkecuali di perguruan tinggi ${ }^{4}$. Menurut Goodwin, pola pikir guru (dan karenanya guru pendidikan / pendidik) perlu ditumbuhkan dalam empat dimensi dalam konteks globalisasi: kurikuler, profesional, moral, dan pribadi 5. Masyarakat pun mesti diberikan pendidikan terkait memperkuat nilai-nilai religiusitas dalam menghadapi bencana Covid-19 yang begitu destruktif.

Komunikasi efektif dipandang sebagai upaya yang dibutuhkan dalam rangka menenangkan masyarakat menghadapi situasi bencana ${ }^{6}$. Menurut Carl Hovland komunikasi dalam dimensi modernitas bertransformasi dari sekedar pengetahuan (knowledge) menjadi ilmu (science) ${ }^{7}$. Komunikasi dan dakwah merupakan bagian integral yang tidak dapat dipisahkan dari agama Islam. Dakwah memiliki peranan penting dalam mengajak masyarakat untuk beriman kepada Allah serta meningkatkan nilai-nilai spiritualitas sehingga diharapkan terbentuknya karakter yang kuat dan moralitas akhlak yang terpuji. Menurut Abdullah bin Ibrāhīm AtTharīqī seorang ulama kontemporer, aktifitas dakwah harus dibangun dari lima prinsip utama; niat ikhlas dalam berdakwah, berbasis kekeluargaan, menghindari hawa nafsu, bersikap bijaksana dan seimbang wasathiyyah, serta optimis dalam mengajak kebaikan kepada orang lain ${ }^{8}$. Selaras dengan At-Thariqi, Syeikh Abdurrahman Al-Arefe seorang guru besar pada bidang studi perbandingan agama-

${ }^{4}$ Zoyah Kinkead-Clark, "Early Childhood Care and Education in Jamaica. Stakeholders' Perceptions of Global Influences on a Local Space," Early Child Development and Care 187, no. 10 (2017): 1484-1495; Sonia Nieto, "Diversity, Globalization, and Education: What Do They Mean for Teachers and Teacher Educators?," Kappa Delta Pi Record 49, no. 3 (2013): 105-107; Peter A. Weldon et al., "Globalization and Higher Education in Southern California: Views from the Professoriate," Compare 41, no. 1 (2011): 5-24; Malcolm Tight, "Globalization and Internationalization as Frameworks for Higher Education Research," Research Papers in Education 36, no. 1 (2021): 52-74, https://doi.org/10.1080/02671522.2019.1633560; Keith Watson, “The Impact of Globalization on Educational Reform and Language Policy: Some Comparative Insights from Transitional Societies," Asia Pacific Journal of Education 21, no. 2 (2001): 1-18; Robert F. Bruner and Juliane Iannarelli, "Globalization of Management Education," Journal of Teaching in International Business 22, no. 4 (2011): 232-242; Severino Machingambi, "The Impact of Globalisation on Higher Education: A Marxist Critique," Journal of Sociology and Social Anthropology 5, no. 2 (2014): 207-215.

${ }^{5}$ A. Lin Goodwin, "Globalization, Global Mindsets and Teacher Education," Action in Teacher Education 42, no. 1 (2020): 6-18, https://doi.org/10.1080/01626620.2019.1700848.

${ }^{6}$ Dewi Soyusiawaty, "Strategi Humas Dalam Menjalin Good Relationship Dengan External Stakeholders UAD," Komuniti: Jurnal Komunikasi dan Teknologi Informasi 8, no. 2 (2016): 102-110; M Burhan Bungin, "Masyarakat Indonesia Kontemporer Dalam Pusaran Komunikasi," Jurnal Komunikasi Pembangunan 1, no. 2 (2011): 125-136, http://jurnalaspikom.org/index.php/aspikom/issue/download/6/3.

${ }^{7}$ Zikri Fachrul Nurhadi and Achmad Wildan Kurniawan, "Kajian Tentang Efektivitas Pesan Dalam Komunikasi," Jurnal Komunikasi Hasil Pemikiran dan Penelitian 3, no. 1 (2017): 90-95.

${ }^{8}$ Abdullah bin Ibrāhīm At-Tharīqū, "Fiqh At-Ta'āmul Ma'a Al-Mukhālif” (Riyadh Saudi Arabia: Dar Al-Wathan, 2010). 
4 |Jurnal Dakwah dan Komunikasi, Vol.6 No.1, 2021

agama, dalam risalah karya kitabnya berjudul Istamti' Bi Hayātika Funūn At-Ta'ämul Ma'a An-Nās fi Diilli As-Sirah An-Nabawiyyah berpendapat bahwa dakwah yang dikembangkan oleh Rosulullah SAW untuk mengajak masyarakat Arab Jahiliyyah pada saat itu lebih mengedepankan prinsip moralitas akhlak terpuji 9. Misi utama para Nabi dan Rasul menurut Muhammad bin Abdullah Ad-Dawis yaitu untuk merekatkan persatuan umat agar tidak tercerai-berai ${ }^{10}$. Saat ini, aktivitas dakwah diberbagai belahan dunia menjadi perhatian serius bagi para intelektual untuk mengamati fenomena-fenomena yang terjadi dalam dunia globalisasi ${ }^{11}$.

Maraknya pengguna media sosial saat ini, digunakan oleh Sebagian umat Islam di Indonesia dalam rangka upaya meningkatkan wacana keagamaan dan aktivias dakwah. Internet, berdampak besar terhadap pola penyebaran beragam interpretasi dalam memahami agama Islam, termasuk pemahaman Islam yang eksklusif dan konservatif ${ }^{12}$. Generasi millennial merupakan salah satu generasi yang dijadikan target sasaran oleh oknum-oknum dalam mendoktrinisasi paham-paham berbahaya serta kontradiktif dengan ajaran Islam. Wacana dan diskursus radikalisme yang terus meningkat dalam beberapa dekade terakhir ini membuat kecemasan dikalangan para intelektual maupun cendekiawan 13. Dalam studi ilmiah yang diangkat oleh Vanessa Martin, Radikalisme Islam kemunculannya di Negara Iran sejalan dengan Revolusi Konstitusional pada tahun 1906, bahkan ia mengungkap adanya korelasi antara gerakan radikal dengan latar belakang dan pengaruh individu

${ }^{9}$ Muhammad bin Abdurrahman Al-Arefe, Istamti' Bi Hayätika Funūn At-Ta'āmul Ma'a An-Näs Fì Dzilli As-Sirah An-Nabawiyyab (Saudi Arabia: Sarikah Muslim: Saudi Arabia: Sarikah Muslim, 2011).

${ }^{10}$ Markaz Al-Buhuts wa Al-Dirasah, Fiqh Al-Wafāq (Maktabah Al-Mulk Fahd AlWathaniyyah: Maktabah Al-Mulk Fahd Al-Wathaniyyah, 2012).

${ }^{11}$ Attiya Ahmad, "Explanation Is Not the Point: Domestic Work, Islamic Dawa and Becoming Muslim in Kuwait," Asia Pacific Journal of Anthropology 11, no. 3 (2010): 293 310; Audrey E. Mouser, "Defining 'Modern' Malay Womanhood and the Coexistent Messages of the Veil," Religion 37, no. 2 (2007): 164-174; Jan Stark, "Beyond 'terrorism' and 'State Hegemony': Assessing the Islamist Mainstream in Egypt and Malaysia," Third World Quarterly 26, no. 2 (2005): 307-327; Rodger Shanahan, "Shi a Political Development in Iraq: The Case of the Islamic Da Wa Party," Third World Quarterly 25, no. 5 (2004): 943-954.

${ }^{12} \mathrm{~B}$ Bräuchler, "Cyberidentities at War: Religion, Identity, and the Internet in the Moluccan Con- Flict," Indonesia 75 (2003): 123-151; J Y Hui, "The Internet in Indonesia: Development and Impact of Radical Websites.," Studies in Conflict \& Terrorism 33, no. 2 (2010): 171-191.

${ }^{13}$ Merrindahl Andrew, "Women's s Electoral Lobby on the Continuum of Radicalism" 29, no. 82 (2015): 366-377; Paul Buhle, "Toward the Understanding of the Visual Vernacular: Radicalism in Comics and Cartoons," Retbinking Marxism 18, no. 3 (2006): 367-381; Olga Fedotova, "Radicalism and Terrorism Problems in a Scientific Discourse of Russian Social Sciences," Procedia - Social and Behavioral Sciences 92 (2013): 334-343; Philip Schofield, "Jeremy Bentham, the French Revolution and Political Radicalism," History of European Ideas 30, no. 4 SPEC.ISS. (2004): 381-401; Kamaruzaman Yusof, Iran Herman, and Badlihisham Mohd Nasir, "Islamic Radicalism in Malaysia: Gender Perspective," Procedia Social and Behavioral Sciences 5 (2010): 2119-2125. 
maupun kelompok dalam mengembangkan perspektif dan identitas politik radikal ${ }^{14}$. Al-Qardhawi seorang ulama modern abad ini menggagas konsep wasathiyyah dalam rangka mengembangkan pola dakwah yang lebih fleksibel dan solusi alternatif tanpa mengundang konflik polemic baru ${ }^{15}$. konsep dakwah wasathiyyah dibangun atas lima pilar at-tawāsut (jangan tengah), at-tawāzun (seimbang), I'tidāl (lurus), tasāmuh (toleransi), musāwah (egaliter), syūra (musyawarah), islāh (revolusi), awlawiyyah (prioritas), tathāwwur (dinamis) ${ }^{16}$. Aktivitas dakwah online di Indonesia dalam dua dekade terakhir sangat di respon baik oleh masyarakat, khususnya generasi milenial. Kehadiran teknologi media sosial memberikan nuansa dinamika baru bagaimana kegiatan dakwah online dapat ditampilkan dalam potret menarik dalam bentuk teks, video, maupun audio yang bisa dikemas sesuai dengan keinginan audiens. Kemunculan para dai-dai kreatif seperti ustadz Abdul Somad, ustadz Hanan Attaki, ustadz Adi Hidayat, Gus Baha, dan yang lainnya, mampu mengambil peran penting dalam membangun umat menuju peradaban yang Islami ${ }^{17}$. Fenomena dakwah online yang dilakukan oleh para penceramah nasional dipandang sebagai kegiatan yang positif dalam meningkatkan spirit beragama dan mendorong religiusitas menuju peradaban manusia yang religius. Mahasiswa merupakan salah satu target sasaran dalam gerakan dakwah online, oleh sebabnya diperlukan upaya-upaya serius dari para praktisi pendidikan dalam memonitor rambu-rambu yang dapat mengurangi dampak buruk yang ditimbulkan akibat tidak adanya kontrol salah satunya adalah penetrasi ideologi-ideologi kontradiktif dengan ajaran nilai-nilai agama Islam.

Studi ini dirancang dalam rangka menelusuri penggunaan sarana online oleh mahasiswa dalam rangka mengoptimalkan peran dakwah melalui media sosial dalam dimensi globalisasi. Kehadiran pandemi Covid-19 turut serta mengubah pola interaksi mahasiswa terhadap aktivitas dakwah yang dilakukan oleh para ustadz maupun dai. Penelitian ini dirasa sangat penting dalam rangka mengetahui dan memahami pola-pola seperti apakah dakwah yang cocok dan selaras bagi mahasiswa dalam kondisi pandemic. Adapun rumusan penelitian yang diangkat yaitu mengetahui pendapat mahasiswa dalam merespon dakwah online yang digagas oleh

${ }^{14}$ Vanessa Martin, "Islamist Radicalism in the Provinces of Iran 1906-9: A Stage in the Development of Islamism," Middle Eastern Studies 53, no. 5 (2017): 687-699, http://dx.doi.org/10.1080/00263206.2017.1288619.

${ }^{15}$ Yusuf Al-Qardhawi, Figh Al-Wasathiyyah Al-Islamiyyah Wa At-Tajdid Ma'älimu Wa Manärätu (Cairo: Maktabah Wahbah, 2009); Yusuf Al-Qardhawi, Fiqh Al-Wasatbiyyah AlIslämiyyah Wa At-Tajdìd Ma'älimu Wa Manārātu (Mesir Kairo: Cairo: Maktabah Wahbah, 2009), https://www.al-qaradawi.net/node/5066.

${ }^{16}$ Mohamad Fahri and Ahmad Zainuri, "Moderasi Beragama Di Indonesia," Intizar 25, no. 2 (2019): 95-100.

${ }^{17}$ Muhammad Munir, "Fenomena Dakwah Online Dan Offline Ustadz Abdus Somad Di Pondok Pesantren Al-Amien Prenduan Sumenep Madura Pendahuluan Ketenteraman Dalam Kehidupan Masyarakat Merupakan Salah Satu Harapan Seluruh Masyarakat Didunia , Tidak Juga Masyarakat Yang Di Kehidupa," Islamic Management and Empowerment 1, no. 1 (2019): 129-142. 
6|Jurnal Dakwah dan Komunikasi, Vol.6 No.1, 2021

para da'i nasional serta mengukur dan mengetahui bagaimana strategi-strategi mereka dalam rangka menggalakan dakwah islam kepada masyarakat dalam masa pandemic Covid-19.

\section{Literature Review}

Dakwah kontemporer memiliki karakteristik dan keunikan tersendiri dibandingkan dengan aktivitas-aktivitas dakwah yang berkembang pada zaman terdahulu. Wacana dakwah menjadi pusat perhatian utama bagi para periset baik nasional maupun internasional terlebih pasca munculnya fenomena-fenomena baru baik yang bersifat positif maupun negative. Sisi positifnya adalah munculnya gerakan model dakwah baru seperti yang di kaji oleh Eva Nisa yang dipublikasikan dalam Jurnal Indonesia and the Malay World terkait gerakan dakwah sosial One Day One Juz. Artikel ini berfokus pada penggunaan media sosial dalam dakwah One Day One Juz (ODOJ), yang berupaya memotivasi umat Islam untuk lebih giat berinteraksi dengan Al-Quran melalui aplikasi WhatsApp. ODOJ melahirkan gaya baru pada ruang public serta menawarkan transformasi bentuk media dalam konteks keagamaan di Indonesia ${ }^{18}$. Adapula riset yang diangkat oleh Crawford dimana ia menemukan bahwa gerakan radikal yang digagas oleh kelompok ekstrimis Wahabbi menggunakan corak kekerasan dalam gaya berdakwahnya. Gerakan yang lahir sekitar abad ke-17 ini mulai berkembang cepat di kota Al-Uyaynah ${ }^{19}$. Shanahan bahkan membuktikan adanya peningkatan gerakan dakwah yang dilakukan oleh kelompok Syi'ah pasca invasi militer ke Irak, gerakan dakwahnya mencoba mengambil pengaruh politik di negaranya ${ }^{20}$. Di negara Yaman, seorang peneliti bernama Shainool mencoba menelusuri gerakan dakwah yang dipopulerkan oleh kelompok Isma'ili ${ }^{21}$.

Peran dakwah tidak hanya berfokus pada internal agama saja, namun rupanya gerakan dakwah telah berkembang menjadi dialog antar-agama dan antar budaya. Studi yang diangkat oleh Weismann memperlihatkan adanya peletakan fondasi dialog-dialog yang dilakukan oleh empat tokoh muslim modern Asghar Ali Engineer asal India, Wahiduddin Khan, Ismail Raji Al-Faruqi dan Tariq Ramadhan. Secara bersama-sama, para aktivis intelektual ini memetakan lintasan Islam modern dari harapan liberal pra-Islamis awal hingga upaya pasca-dan neo-Islamis saat ini

${ }^{18}$ Eva F. Nisa, "Social Media and the Birth of an Islamic Social Movement: ODOJ (One Day One Juz) in Contemporary Indonesia," Indonesia and the Malay World 46, no. 134 (2018): 24-43.

${ }^{19}$ M. J. Crawford, "The Da wa of Ibn 'Abd Al-Wahhāb before the Al Sa ūd," Journal of Arabian Studies 1, no. 2 (2011): 147-161.

20Shanahan, "Shi a Political Development in Iraq: The Case of the Islamic Da Wa Party."

${ }^{21}$ Shainool Jiwa, "The Genesis of Ismā'ĪlI I Da'Wa Activities in the Yemen," British Society for Middle Eastern Studies. Bulletin 15, no. 1-2 (1988): 50-63. 
untuk menavigasi antara globalisasi yang didominasi Barat dan jihadisme Islam ${ }^{22}$. Wacana gerakan dakwah yang diangkat oleh para intelektual internasional dalam diskursus Indonesia salah satunya adalah Cris Chaplin, ia melihat bahwa ideologi Islam Salafi telah bertransformasi dan menyebar cepat dikalangan pelajar mahasiswa di Yogyakarta Indonesia. Chaplin melihat bahwa dakwah yang dikembangkan dikampus-kampus di Yogyakarta rupanya Sebagian diantaranya ada yang memiliki misi tertentu dalam rangka mengangkat citra Wahabbi 23. Dakwah sosial media dengan wacana semangat taqwa berbasis di Bandung menarik perhatian Lengaueur, seorang ilmuwan internasional ${ }^{24}$. Penelitian terhadap dai pun rupanya diangkat oleh peneliti luar, salah satunya Wai Wew Heng dalam risetnya berjudul The Art of Dakwah: social media, visual persuasion and the Islamist propagation of Felix Siauw, riset ini menyoroti (a) persimpangan antara aktivitas online dan acara offline dalam dakwah Islam kontemporer; (b) berbagai bentuk ekspresi lisan, tekstual dan visual dakwah on-offline; dan (c) politik dan puisi dakwah. Heng memandang bagaimana dakwah online dan visual saling melengkapi daripada menggantikan dakwah offline dan tekstual. Felix Siauw menurut Heng secara kreatif menggunakan media sosial dan gambar visual untuk menyebarkan ideologi HTI di kalangan anak muda Muslim Indonesia. Pendekatan dakwahnya menghibur namun konservatif, santai tapi dogmatis, dan personal tapi politis ${ }^{25}$. Secara garis besar gerakan dakwah offline maupun online dapat menjadi satu senjata yang dapat digunakan dalam hal positif maupun negative ${ }^{26}$.

\section{Metode Penelitian}

Studi penelitian menggunakan pendekatan kuantitatif dengan menggunakan Teknik quosioner menggunakan google form secara online. Pengumpulan data

\footnotetext{
${ }^{22}$ Itzchak Weismann, "Between Da'wa and Dialogue: Religious Engagement in Muslim-Minority Environments," Islam and Christian-Muslim Relations 30, no. 4 (2019): 505 522, https://doi.org/10.1080/09596410.2019.1601909.

${ }^{23}$ Chris Chaplin, "Salafi Activism and the Promotion of a Modern Muslim Identity: Evolving Mediums of Da'wa amongst Yogyakartan University Students," South East Asia Research 26, no. 1 (2018): 3-20.

${ }^{24}$ Dayana Lengauer, "Sharing Semangat Taqwa: Social Media and Digital Islamic Socialities in Bandung," Indonesia and the Malay World 46, no. 134 (2018): 5-23.

${ }^{25}$ Wai Weng Hew, "THE ART OF DAKWAH: Social Media, Visual Persuasion and the Islamist Propagation of Felix Siauw," Indonesia and the Malay World 46, no. 134 (2018): 61-79.

${ }^{26}$ Weismann, "Between Da wa and Dialogue: Religious Engagement in MuslimMinority Environments"; Jessica R. Ham, "Cooking to Be Modern but Eating to Be Healthy: The Role of Dawa-Dawa in Contemporary Ghanaian Foodways," Food, Culture and Society 20, no. 2 (2017): 237-256, http://dx.doi.org/10.1080/15528014.2017.1305827; Aaron Rock, "Amr Khaled: From Da'wa to Political and Religious Leadership," British Journal of Middle Eastern Studies 37, no. 1 (2010): 15-37; Ahmad, "Explanation Is Not the Point: Domestic Work, Islamic Dawa and Becoming Muslim in Kuwait."
} 
8 Jurnal Dakwah dan Komunikasi, Vol.6 No.1, 2021

menggunakan Teknik random sampling, Adapun jumlah partisipan pada riset ilmiah kali ini berjumlah 36 partisipan. Partisipan diambil dari mahasiswa jurusan manajemen administrasi disalah satu perguruan tinggi di kota Bandung. Adapun proses pengumpulan data responden penelitian dilaksanakan pada awal tahun 2020. Data yang diperoleh di analisis dengan menggunakan berbagai pendekatan salah satunya pendekatan sosiologi dan pendekatan agama. Rincian partisipan dapat dilihat dari table dibawah ini:

Table 1 Partisipan Quesioner

\begin{tabular}{cc}
\hline Administrasi Pendidikan & Jumlah Partisipan \\
\hline Angkatan 2017 & 15 \\
\hline Angkatan 2018 & 4 \\
\hline Angkatan 2019 & 17 \\
\hline Jumlah & 36 \\
\hline
\end{tabular}

Adapun instrument yang kami lemparkan kepada para responden meliputi 8 pertanyaan diantaranya:

1) Berapa lama intensitas penggunaan media sosial dalam jangka perhari

2) Berapa lama intensitas anda mengakses kajian dakwah islami secara online

3) Media apakah yang paling sering anda gunakan sebagai kajian dakwah online

4) Konten atau isu-isu seperti apakah yang menarik bagi anda terkait dakwah online

5) Siapakah tokoh penceramah yang paling anda kagumi dan inspirasi

6) Apakah konten dakwah online dapat meningkatkan religiusitas anda

7) Adakah dorongan anda untuk men-share dakwah yang anda suka kepada orang lain

8) Bagaimanakah pendapat anda terkait dakwah yang efektif dan efisien

9) Bagaimanakah pendapat anda terkait tantangan dan problematika dakwah online saat ini

10) Bagaimanakah solusi yang anda tawarkan dalam menjawab problematika dakwah online pada saat ini 


\section{Hasil Penelitian}

Dari data tanggapan responden yang masuk, penulis coba gambarkan dalam table seperti dibawah ini:

Table 2 Hasil Tanggapan Dari Responden

\begin{tabular}{|c|c|c|}
\hline No & Instrument Pertanyaan & Tanggapan Responden \\
\hline 1 & $\begin{array}{l}\text { Intensitas Penggunaan Media } \\
\text { Sosial Dalam Satu Hari }\end{array}$ & $\begin{array}{l}25 \% \text { sebanyak } 12 \text { jam lebih, } 22,2 \% \\
\text { sebanyak } 12 \text { jam, } 27,8 \% \text { sebanyak } 6 \text { jam, } \\
11,1 \% \text { sebanyak } 4-5 \text { jam, sisanya dibawah } \\
3 \text { jam sehari }\end{array}$ \\
\hline 2 & $\begin{array}{l}\text { Lama mengakses kajian dakwah } \\
\text { islami secara online }\end{array}$ & $\begin{array}{l}52,8 \% \text { sebanyak } 1 \text { jam kurang, } 27,8 \% \\
\text { sebanyak } 1 \text { jam, } 8,3 \% \text { sebanyak } 3 \text { jam, } \\
\text { sisanya dibawah } 1 \text { jam. }\end{array}$ \\
\hline 3 & Penggunaan media & $\begin{array}{l}\text { Youtube sebesar 58,3\%, Instagram } \\
\text { sebesar 83,3\%, Line 11,1\%, WhatsApp } \\
\text { 13,9\%, Twitter 2,8\%, Google 2,8\%. }\end{array}$ \\
\hline 4 & Konten dan Isu Dakwah Online & $\begin{array}{l}\text { Kasih sayang dan Azab Allah sebesar } \\
41,7 \% \\
\text { Kajian Sunnah Rosulullah 50\% } \\
\text { Kajian Al-Quran 41,7\% } \\
\text { Motivasi dan Inspirasi Hidup 86,1\% } \\
\text { Konsep Pendidikan Dalam Islam 27,8\% } \\
\text { Pernikahan 25\% } \\
\text { Tergantung Admin 5,6\% } \\
\text { Lain-lain 2,8\% }\end{array}$ \\
\hline 5 & $\begin{array}{l}\text { Tokoh Penceramah Inspirasi } \\
\text { Anda }\end{array}$ & $\begin{array}{l}\text { Ustadz Hanan Attaki sebesar 63,9\% } \\
\text { Ustadz Abdul Somad 33,3\% } \\
\text { Ustadz Khalid Basalamah 13,9\% } \\
\text { Ustadz Adi Hidayat 33,3\% } \\
\text { Ustadz Handy Bonny 2,8\% } \\
\text { KH. Quraish Shihab 2,8\% } \\
\text { Gus Miftah 2,8\% } \\
\text { Lain-lain 2,8\% }\end{array}$ \\
\hline 6 & $\begin{array}{l}\text { Kajian Dakwah Islami } \\
\text { Meningkatkan Nilai Religiusitas }\end{array}$ & $\begin{array}{l}\text { Sangat Berpengaruh sebesar } 36,1 \% \\
\text { Terkadang Berpengaruh sebesar } 63,9 \% \\
\text { Tidak Berpengaruh sebesar } 0 \%\end{array}$ \\
\hline 7 & $\begin{array}{l}\text { Dorongan Menshare konten } \\
\text { dakwah kepada orang lain }\end{array}$ & $\begin{array}{l}\text { Kadang-kadang } 86,1 \% \\
\text { Tidak Pernah } 13,9 \% \\
\text { Selalu sebesar } 0 \%\end{array}$ \\
\hline 8 & Dakwah yang efektif dan efisien & $\begin{array}{l}\text { Mayoritas Responden menyatakan bahwa } \\
\text { dakwah yang efektif dan efisien adalah } \\
\text { dakwah yang Sesuai dengan Al Quran } \\
\text { dan Hadits, Memperhatikan sasaran } \\
\text { dakwah, Pembahasan }\end{array}$ \\
\hline
\end{tabular}




\begin{tabular}{cl}
\hline & Memotivasi, Tidak menggurui, Tidak \\
& radikal, Menyampaikan dalil dan kasus \\
& yang sesuai, Tenang dan bijaksana, \\
& Mengikuti kemajuan teknologi, \\
& Komunikatif dan Bahasa gaul/kekinian \\
\hline T. Tantangan dan Problematika & Mayoritas Responden menyatakan bahwa \\
dakwah Islami pada saat ini & tantangan dan problematika dakwah \\
& Islamiyah masa kini adalah Bersaing \\
& dengan konten lain, Kurang menarik, \\
& Dicampurbaurkan dengan kepentingan \\
& politik, Ketidakjelasan sumber materi, \\
& Perpecahan Islam, Dampak negatif \\
& modernisasi, Penyampaian dakwah yang \\
& membosankan, Pluralisme, Sekularisme, \\
& Radikalisme dan Islamphobia. \\
\hline Solusi yang anda tawarkan dalam & Mayoritas Responden menyatakan bahwa \\
menghadapi problematika & solusi untuk tantangan dan problematika \\
dakwah islami pada saat ini & tersebut adalah Kreatif dan inovatif \\
& menarik perhatian orang lain, Perbanyak \\
& dakwah melalui media sosial dan \\
& kekinian, Memperhatikan sasaran \\
& dakwah, Sertakan dengan sumber yang \\
shahih, Mengoptimalkan IT, Saling & menghargai dan menghormati, \\
& Humor/candaan, Percaya diri, Sabar dan \\
& tawakal. \\
\hline &
\end{tabular}

\section{Diskusi dan Pembahasan}

Dari data-data statistic diatas, penulis melihat beberapa hasil yang dapat didiskusikan lebih lanjut menggunakan berbagai Analisa yang ada:

Pertama, pergeseran pola hidup, pola aktivitas dari yang seharusnya efektif kepada hal-hal yang cenderung negative yaitu dengan menghabiskan waktu untuk hal-hal yang kurang bermanfaat. Hal ini bisa dilihat dari data statistic dimana $25 \%$ lebih mereka menghabiskan 12 jam perhari untuk berselayar dimedia online. Jika ditotal, maka kurang lebih 75\% rata-rata menghabiskan lebih dari 6 jam perhari hanya untuk melihat internet. Berbanding terbalik dengan aktivitas keagamaan, mayoritas 80\% mengakui tidak lebih dari 1 jam mereka habiskan mengikuti kajian dakwah online. Ketimpangan yang begitu jauh antara aktivitas positif dengan aktivitas negative 1:6 seharusnya sudah menjadi perhatian serius kita Bersama untuk mencari cara meminimalisir dampak aktivitas negative ini. Fenomena ini tentunya dikritik oleh ajaran agama Islam, waktu merupakan asset berharga, oleh sebab itu kaum muslimin dituntut untuk memanfaatkannya sebaik mungkin. Dalam sebuah 
kata bijak berkata "waktu itu bagaikan pedang, apabila anda tidak bisa memotongnya, maka ia akan memotong mu". Dalam Al-Quran sendiri, secara tegas Allah SW'T memerintahkan umat Islam agar selalu produktif dalam memanfaatkan waktu. Dalam QS. Al-Asr Allah bahkan menggunakan kalimat sumpah yang dinisbatkan kepada al-'asr demi masa, hal ini menunjukkan begitu urgennya waktu bagi kehidupan manusia. Seorang peneliti Barat bernama Hirschkind (2009) bahkan menyatakan bahwa kelompok reformis dengan gerakan islamisasinya menuduh hegemoni global budaya Barat telah merusak budaya Islam, menyerang ajaran agama, dan kehidupan muslim menggunakan senjata media massa, budaya populer seperti film, music, dan system pendidikan sekuler. Gharwu Al-Fikr (perang pemikiran) diyakini oleh kelompok reformis sebagai sesuatu yang harus diwaspadai dan harus diantisipasi, karena dipandang akan sangat berbahaya terlebih dalam dimensi modernitas ${ }^{27}$.

Kedua, Youtube dan Instagram merupakan dua media sosial online yang paling digemari untuk digunakan dalam kajian dakwah islam. Diurutan selanjutnya WhatsApp, lalu disusul Line, dan Google diposisi terakhir. Seorang pakar pendidikan dunia Boby De Porter dalam bukunya Quantum Learning menemukan adanya peningkatan kecerdasan intelektual siswa apabila proses pembelajaran mampu melibatkan seluruh panca indera dengan konsep audio-visual. Youtube dan Instagram menurut penulis memiliki keunggulan konsep audio-visual yang ramah dan simpel dengan dibandingkan yang lainnya, walaupun WhatsApp sudah mulai mengembangkan teknologi Audio-Visual yang lebih praktis secara bertahap. Dalam pandangan analisis penulis, ada satu konsep yang lebih efektif dan effisien dibandingkan teori Audio-Visual yang ditawarkan oleh Porter dalam meningkatkan intelektualitas yaitu dengan prinsip tarbiyyah Rosulullah SAW At-Thathbiq Al-'Amali mengaktulisasikan pengetahuan (science) dengan tindakan (action). Prinsip tarbiyyah islamiyyah Rosulullah tersebut dikembangkan oleh seorang pakar pendidikan Prof Muhamma Rawwas dalam karyanya Dirāsāt At-Tablïliyyah Li Syabsyiyati Ar-Rasūl Muhammad, setidaknya ada tujuh belas prinsip efektif pola pendidikan Rosulullah SAW yang diterapkan kepada para sahabatnya sehingga melahirkan manusiamanusia religius, salah satunya prinsip diatas ${ }^{28}$.

Ketiga, tema-tema dakwah yang dipilih oleh responden bisa dilihat bahwa sebanyak 50\% mereka gemar untuk mengkaji Sunnah Rosulullah, lalu 41,7\% Kajian Al-Quran dan Surga-Neraka, 86,1\% memilih Tema Kajian Motivasi dan Inspirasi Hidup, 27,8\% terkait pendidikan islam, 25\% tema pernikahan. Jika dilihat dari statistik, penulis menyimpulkan bahwa adanya beban dan tekanan yang begitu luar biasa yang dihadapi oleh mahasiswa sehingga tema yang mereka cari lebih berkaitan dengan bagaimana memotivasi dan mencari inspirasi-inspirasi positif yang dapat

\footnotetext{
${ }^{27} \mathrm{C}$ Hirschkind, The Ethical Soundscape: Cassette Sermons and Islamic Counterpublics (New York: Columbia University Press, 2009).

${ }^{28}$ Muhamad Rawwas, "Dirasah Tahliliyyah Li Syahshiyati Ar-Rasul Muhammad" (Lebanon Beirut: Dar An-Nafais, 1988).
} 
menekan tingkat stress yang mereka alami. Apa yang dialami oleh mereka selaras denga napa yang ditemukan oleh Goodwin dalam studi ilmiahnya, dimana ia menyimpulkan bahwa arus globalisasi telah mempengaruhi dunia pendidikan pada saat ini. Goodwin bahkan mendorong para dosen agar mampu beradaptasi dengan perubahan ini minimal dengan membangun empat dimensi yaitu kurikuler, professional, moralitas dan kepribadian individu ${ }^{29}$. Lebih lanjut, pakar agama Dr Abdurrahman Al-Arefe dalam karyanya berpendapat bahwa umat Islam dalam dimensi modernitas dan globalisasi dituntut untuk terus mengembangkan bakat dan potensinya sehingga mampu menjadi seorang manusia yang unik dan unggul ${ }^{30}$. Tekanan yang hebat yang dirasakan oleh masyarakat modern saat ini betul-betul harus diantisipasi salah satunya yaitu meningkatkan nilai-nilai spiritualitas sehingga mampu menjalin komunikasi intens dengan Allah SWT. penanaman nilai-nilai karakter positif setidaknya sudah menjadi agenda besar para praktisi pendidikan untuk menemukan formulasi yang efektif dan efisien dalam meningkatkan religiusitas masyarakat kontemporer ${ }^{31}$.

Keempat, kepribadian penceramah serta gaya komunikasinya menjadi magnet bagi para audien dalam mendengarkan dakwahnya. Hal ini bisa dibuktikan dengan hasil responden dimana sebesar $63,9 \%$ mereka memilih dan menyukai gaya dakwah yang dilakukan oleh Ustadz Hanan Attaki. Diposisi selanjutnya sebesar 33,3\% diraih oleh Ustadz Abdul Somad dan Ustadz Adi Hidayat, lalu 13,9\% memilih Ustadz Khalid Basalamah. Sebanyak 2,8\% responden berbeda-beda pilihan yaitu Quraish Shihab, Gus Miftah, Handy Bonny, dan lain-lain. Fenomena pilihan ini menurut Prof Muhammad Rawwas bukan hal baru, rupanya Rosulullah SAW pun telah mencontohkan hal demikian dalam prinsip pendidikannya yaitu Al-Khitäb Alà Qadri Fahmi Uqülibim berdialoglah sesuai kapasitas intelektual mereka ${ }^{32}$. Penulis melihat adanya keselaran prinsip diatas dengan hasil riset, berhubung responden Sebagian besar merupakan mahasiswa yang notabene nya berusia 20-25 tahun, sehingga sangat cocok sekali mereka memilih Hanan Attaki dalam kajian dakwahnya karena ia seorang ustadz muda dan gaya berkomunikasinya bercorak "gaul" yang

\footnotetext{
${ }^{29}$ Goodwin, "Globalization, Global Mindsets and Teacher Education."

${ }^{30} \mathrm{Al}$-Arefe, Istamti' Bi Hayätika Funūn At-Ta'ämul Ma'a An-Nās Fì Drilli As-Sìrah An-Nabawiyyah.

${ }^{31}$ Ali Imron, "Pendidikan Kepribadian Anak Menurut Abdullah Nashih Ulwan," Edukasia Islamika 1, no. 1 (2016): 89-118; Ibadullah Malawi, "Implementasi Pendidikan Karakter Melalui Pembelajaran Dalam Mata Pelajaran Di Sekolah Dasar," Premiere Educandum: Jurnal Pendidikan Dasar dan Pembelajaran 3, no. 01 (2016): 1-12; Ahmad Yasar Ramdan and Puji Yanti Fauziah, "Peran Orang Tua Dan Guru Dalam Mengembangkan Nilai-Nilai Karakter Anak Usia Sekolah Dasar," Premiere Educandum : Jurnal Pendidikan Dasar dan Pembelajaran 9, no. 2 (2019): 100; Miftah Mucharomah, "Pendidikan Karakter: Sebuah Visi Islam Rahmatan Lil Alamin,” Edukasia Islamika 2, no. 2 (2017): 191-207; Puspo Nugroho, "Internalisasi Nilai-Nilai Karakter Dan Kepribadian Mahasiswa Pendidikan Agama Islam Melalui Pendekatan Humanis-Religius," Edukasia: Jurnal Penelitian Pendidikan Islam 12, no. 2 (2017): 355.

${ }^{32}$ Rawwas, "Dirasah Tahliliyyah Li Syahshiyati Ar-Rasul Muhammad."
} 
menjadi kesukaan generasi muda. Dakwah online merupakan gaya dakwah baru yang berpotensi menjadi gerakan sosial jamaiy. Pernyataan ini setidaknya dipertegas dengan bukti riset yang dilakukan oleh Wiktorowicz (2001) menurutnya jaringan sosial memainkan peran penting dalam perekrutan gerakan sosial dan ini juga berlaku untuk gerakan dakwah liqa. Jaringan sosial mereka terutama dibangun melalui kekerabatan dan hubungan pribadi. ${ }^{33}$.

Kelima, kajian dakwah online diyakini mampu meningkatkan religiusitas. Hal ini bisa dilihat dari jawaban responden yang mana semuanya menjawab adanya dampak terhadap religiusitas dan kesalehan mereka pasca mengikuti kajian. Menurut penulis, keimanan merupakan wilayah yang bersifat fluktuatif naik turun, meningkatkan spiritual keimanan bisa dengan cara meningkatkan ibadah maupun dengan cara meningkatkan keilmuan. Hal ini telah banyak disinggung baik didalam Al-Quran maupun As-Sunnah terkait keutamaan ilmu. Namun demikian, Dr Khalid Abu Syadi menyarankan dalam karyanya Bi Ayyi Qalb Nalqāhu bahwa keilmuan yang didapatkan sudah seyogyanya sejalan dengan penerapannya ${ }^{34}$. Para ulama Rabbani dahulu seperti Ikrimah dalam menerima murid-muridnya menerapkan aturan ketat yaitu diharuskan mengamalkan dari ilmu yang didapatkan selama proses pembelajaran. Penerapan aturan ketat ini rupanya diikuti pula oleh ulama lainnya seperti Sufyan At-Tsauri, Sari bin Al-Mughallis Al-Suqthi berkata "setiap anda mendapatkan tambahan ilmu, maka berhati-hatilah karena hal ini akan menjadikan hujjah kepada Anda lebih ketat" ${ }^{35}$. Selaras dengan pernyataan diatas, Lengauer menyelidiki ekspresi kesalehan (taqwa) kontemporer dan pembentukan diri Muslim yang saleh di seluruh ranah interaksi online dan offline pada komunitas semangat sharing taqwa di Bandung ${ }^{36}$.

Keenam, kesadaran minim dikalangan remaja dalam menggalakkan kegiatan berdakwah. Hal ini bisa dikaji dari statistic data dimana 86,1\% menyatakan kadang-kadang menshare konten dakwah kepada sesama, sisanya 13,9\% bahkan tidak pernah sama sekali. Minimnya kesadaran ini menurut hemat penulis dapat diantisipasi dengan mengedukasi beberapa keutamaan dan manfaat yang akan didapatkan oleh mereka tatkala mau berbagi kebaikan kepada sesama. Kesadaran yang rendah ini sudah diprediksi oleh Boby De Porter dalam Quantum Learning, oleh sebabnya ia mencoba menawarkan gagasan teori AMBAK kepanjangan Apa Manfaatnya Bagi Ku. Fenomena kesadaran rendah setidaknya bisa diantisipasi dengan menjelaskan keutamaan berdakwah baik dari Al-Quran maupun Sunnah. Salah satu hadist yang membicarakan ini yaitu "“Wahai Ali, sesungguhnya Allah swt

\footnotetext{
${ }^{33} \mathrm{Q}$ Wiktorowicz, The Management of Islamic Activism; Salafis, the Muslim Brotherhood, and State Power in Jordan (New York: State University of New York, 2001).

${ }^{34}$ Khalid Abu Syadi, Bi Ayyi Qalb Nalqabu (Mesir: Al-Andalus Al-Jadidah Li AnNasyri Wa At-Tauzi, 2008).

${ }^{35}$ Khalid Abu Syadi

${ }^{36}$ Lengauer, "Sharing Semangat Taqwa: Social Media and Digital Islamic Socialities in Bandung."
} 
memberikan hidayah seseorang dengan usaha kedua tanganmu, maka itu lebih bagimu dari tempat manapun yang matahari terbit di atasnya (lebih baik dari dunia dan isinya)". ${ }^{37}$ Dalam Riwayat lain Rasulullah saw bersabda: "Sesungguhnya Allah swt memberi banyak kebaikan, para malaikat-Nya, penghuni langit dan bumi, sampai semut-semut di lubangnya dan ikan-ikan selalu mendoakan orang-orang yang mengajarkan kebaikan kepada orang lain". ${ }^{38}$

Ketujuh, Dakwah Efektif, Efisien serta tantangan dan Problematikanya. Mayoritas responden menilai bahwa dakwah efektif dan efisien haruslah berlandaskan kepada Al-Quran dan Hadist, memperhatikan sasaran dakwah, tema harus disesuaikan dengan audiens, mampu memotivasi para pendengar, tinggak menggurui, tidak radikal, komunikatif. Pendapat ini setidaknya sejalan dengan apa yang telah digariskan oleh para ulama maupun intelektual dalam kajiannya ${ }^{39}$. Keselarasan wacana dengan intelektualitas audiens bahkan sempat disinggung oleh Gillen Hoke dalam studi risetnya dimana ia menggagas bahwa komunikasi haruslah menggunakan strategi bahkan tidak hanya berlaku bagi kaum pria saja, begitupun bagi kaum wanita ${ }^{40}$. Adapun dalam konteks tantangan dan problematika dunia dakwah saat ini mayoritas responden menjawab diantaranya adalah persaingan konten, gaya komunikasi dirasa kurang menarik, adanya unsur kepentingan politik, mengangkat isu sensitive sehingga khawatir membuat perpecahan, serta maraknya dakwah yang berbau ideologi negative seperti radikalisme, sekularisme, maupun islamophobia. Penulis tertarik untuk menganalisa lebih jauh terkait jawaban adanya unsur kepentingan politik. Fenomena ini agak sedikit mirip dengan gagasan teori yang dikembangkan oleh Zaid Munson dalam risetnya, dimana ia menamakan istilah upaya ganda dengan sebutan Polisemi. Menurutnya polisemi adalah adanya tumpeng tindih aktivitas keagamaan dengan aktivitas lain seperti social, politik maupun yang lainnya, sehingga tidak adanya kesepakatan kategorisasi mana pengalaman maupun aktivitas yang murni wilayah agama, mana pula yang diluar agama. Menurut analisis penulis, penemuan Munson terkait fenomena ini sebetulnya banyak ditemukan dalam dunia modernitas. Agama sering kali dipolitisasi menjadi satu kekuatan untuk mencapai satu tujuan tertentu, bahkan fenomena ini diturunkan menjadi ritual-ritual keagamaan yang dilakukan oleh masyarakat kontemporer pada tatanan praktisnya. penulis ambil contoh, gerakan-gerakan tasawwuf kontemporer dimana banyak studi penelitian internasional yang membuktikan hal tersebut. Intelektual Simon Stjernholm dalam studi ilmiahnya yang dirilis pada journal of Islamic Law and

${ }^{37}$ HR. Al-Hakim dalam Al-Mustadrak

${ }^{38} \mathrm{HR}$. Tirmidzi dari Abu Umamah Al-Bahili

${ }^{39} Y$ usuf Al-Qardhawi, Al-Ijtihäd Fì As-Syarìah Al-Islämiyyah (Cairo: Dar Al-Qalam, 1996); HAMID MOWLANA, "Communication, Philosophy and Religion," Journal of International Communication 9, no. 1 (2003): 11-34; Eric M. Fife, Leigh C. Nelson, and Amber S. Messersmith, "The Influence of Family Communication Patterns on Religious Orientation Among College Students," Journal of Family Communication 14, no. 1 (2014): 72 84; Rawwas, "Dirasah Tahliliyyah Li Syahshiyati Ar-Rasul Muhammad."

${ }^{40}$ Hailey Gillen Hoke, "Sensitive Issues, Religion, and Respect in the Gender and Communication Course," First Amendment Studies 52, no. 1-2 (2018): 114-125, https://doi.org/10.1080/21689725.2018.1511442. 
Culture menyatakan bahwa kaum sufi di London memadukan antara aktivitas keagamaan dengan politik untuk mencapai tujuan tertentu. Dewan Muslim Sufi (The Sufi Muslim Counci) sempat dituduh melakukan serangan teroris di London pada Tahun 2005 sehingga pemerintah sempat menginterograsi kegiatan dakwah mereka ${ }^{41}$. walaupun pada akhirnya mereka membuktikan bahwa tindakan ekstrimis tersebut bukanlah gerakan yang mereka lakukan, tapi tetap saja hal ini menunjukkan bahwa terkadang masyarakat eksternal belum baku memilah mana kelompok keagamaan yang murni menginterpretasikan dakwah keagamaan. Lalu ada pula gerakan sufistik di negara Afrika, studi yang dilakukan oleh Muhammed Haron dimana ia melihat fenomena adanya kompetisi diantara para kelompok thariqah untuk merebut ruang public spiritual di Afrika. Studi ini memfokuskan diri untuk mempelajari gerakan dakwah sufistik kelompok thariqah Chistiyyah, Murabitun, Qadriyyah, Alawiyyah, dan Naqshabandi, pada akhirnya Haron menyimpulkan bahwa kelompok thariqah tersebut bergerak kea rah gerakan institusi social ${ }^{42}$. Gerakan sufistik kontemporer dipandang oleh para ilmuwan dan pakar sosiologi sering dipolitisasi dan dimanfaatkan untuk gerakan-gerakan tertentu seperti politik dan dakwah yang menurut Munson fenomena ini selaras dengan konsep poliseminya ${ }^{43}$.

Fenomena polisemi sebetulnya sudah menjadi perhatian utama para ulama Islam semenjak di utusnya Nabi Muhammad saw. Mungkin penulis melihat

\footnotetext{
${ }^{41}$ Simon Stjernholm, "Sufi Politics in Britain: The Sufi Muslim Council and the 'Silent Majority' of Muslims," Journal of Islamic Law and Culture 12, no. 3 (2010): 215-226.

${ }^{42}$ Muhammed Haron, "Da'wah Movements and Sufi Tariqahs: Competing for Spiritual Spaces in Contemporary South(Ern) Africa ," Journal of Muslim Minority Affairs 25, no. 2 (2005): 261-285.

${ }^{43}$ Barbara Degorge, "Millennial Islam in Africa: Sufi Politics in the Sudan," The European Legacy 5, no. 2 (2000): 195-206; Michael Rywkin, "The Communist Party and the Sufi Tariqat in the Checheno-Ingush Republic," Central Asian Survey 10, no. 1-2 (1991): 133 145; EROL N. GULAY, "The Gülen Phenomenon: A Neo-Sufi Challenge to Turkey's Rival Elite?," Critique: Critical Middle Eastern Studies 16, no. 1 (2007): 37-61; Kazuhiro Arai, "Combining Innovation and Emotion in the Modernization of Sufi Orders in Contemporary Egypt," Critique: Critical Middle Eastern Studies 16, no. 2 (2007): 155-169; Milad Milani and Vassilis Adrahtas, "Modern Talking: Sufi Socio-Political Discourse," Journal of Religious and Political Practice 4, no. 2 (2018): 175-194, https://doi.org/10.1080/20566093.2018.1439813; Christine Thu Nhi Dang, "Erotics, Poetics, Politics: The Spheres of Action of Senegalese Sufi Voices," Ethnomusicology Forum 26, no. 3 (2017): 349-372; Armando Salvatore, "Sufi Articulations of Civility, Globality, and Sovereignty," Journal of Religious and Political Practice 4, no. 2 (2018): 156-174, https://doi.org/10.1080/20566093.2018.1439808; Mikkel Rytter, "Burger Jihad: Fatal Attractions at a Sufi Lodge in Pakistan," Journal of Muslim Minority Affairs 36, no. 1 (2016): 46-61; Tommy Josefsson, Marco Nilsson, and Klas Borell, "Muslims Opposing Violent Radicalism and Extremism: Strategies of Swedish Sufi Communities," Journal of Muslim Minority Affairs 37, no. 2 (2017): 183-195, https://doi.org/10.1080/13602004.2017.1339498; Michael Laffan, “The Makings of Indonesian Islam: Orientalism and the Narration of a Sufi Past," The Makings of Indonesian Islam: Orientalism and the Narration of a Sufi Past 19, no. 5 (2011): 1-301, http://dx.doi.org/10.1080/10848770.2014.943520; Uzma Rehman and Peter LundThomsen, "Social Support at a Sufi Lodge in Punjab, Pakistan," Contemporary South Asia 22, no. 4 (2014): 377-388.
} 
fenomena ini bagian integral yang tidak bisa dipisahkan dari kajian keislaman terkait dengan niat. Penulis melihat bahwa agama merupakan satu pedoman hidup baik didunia maupun diakhirat, sehingga konsekuensinya adalah seluruh aktivitas kehidupan manusia beserta segala aspek-aspeknya seperti politik, ekonomi, dakwah, budaya, sosial, dan yang lainnya tidak bisa dipisahkan dari agama. Justru penulis tidak sepakat tatkala adanya wacana yang digaungkan oleh kelompok barat dengan istilah sekulerisasi yaitu memisahkan agama dengan hal-hal yang bersifat duniawi. Ini merupakan pemikiran filosofis yang tidak diajarkan oleh agama. Banyak ayat AlQuran dan Hadist mempertegas keterkaitan agama dengan seluruh aspek kehidupan manusia. Penulis melihat bahwa sejatinya konsep Munson terkait polisemi aktivitas sebetulnya merupakan hal yang wajar karena tadi agama merupakan pusat aktivitas yang didistribusikan kepada wilayah-wilayah tertentu seperti politik dan sebagainya. Untuk menstandarisasi mana aktivitas keagamaan, mana yang tidak maka dikembalikan lagi kepada konsep tujuan ilahiyyah atau dengan nama familiernya yaitu niat. Apabila niat seseorang melakukan tindakan ikhlas menurut Tuhan dan sesuai dengan aturan-aturan agama, maka hal ini tidak menyalahi. Konsep ini telah disepakati oleh para ulama muslim sebagaimana dalam karya-karyanya ${ }^{44}$.

Dari beberapa analisis diatas, secara garis besar dakwah online mendapat apresiasi yang baik dari para mahasiswa dalam rangka meningkatkan spiritualitas dan kesalehan individu mereka khususnya pada saat ini. beragam problematika yang muncul ditengah-tengah masyarakat dalam masa pandemic ini, dapat menimbulkan kerusakan baik bersifat materi maupun non-materi. Dakwah online dengan mengangkut isu-isu positif mampu mengurangi beban yang dihadapi oleh generasi muda saat ini.

${ }^{44}$ Yusuf Al-Qardhawi, Ushül Al-'Amal Al-Khairī Fì Al-Isläm Fì Dhaui An-Nushūsh Wa Al-Maquasid As-Syarìah (Mesir Kairo: Cairo: Dar As-Syuruq, 2007); Yusuf Al-Qardhawi, Syarìatu Al-Islämiyyah Shälibatun Lil Tathbìq Fì Kulli Zamān Wa Makān (Mesir Kairo: Cairo: Dar As-Shahwah Lil Nasyr Wa Tauji', 1993); Nasir Muhammadi Muhammad Jad, "AlTa’amul Ma'a Ghayr Al-Muslimin Fi 'Ahd Al-Nabawi," 2009; Muḥammad Sacīd Ramaḍān Al-Būțī, "Dhawabith Al-Mashlahah Fi Al-Sya'riah Al-Islamiyyah" (Damaskus: Muassasah Ar-Risalah, 1973); Muhamad Mutawalli As-Sya'rawi, "Al-Ghaib” (Kairo Mesir: Maktabah AlSya'rawi Al-Islamiyyah, 1998); Alauddin Ibnu Al-Laham, "Al-Qawā’id Wa Al-Fawāid AlUshūliyyah Wa Mā Yata’allaq Bihā Min Al-Ahkām Al-Far'iyyah” (Kairo Mesir: As-Sunnah Al-Muhammadiyyah, 1956); Izat 'Ubayd Al-Da'as, “Al-Qawa'id Al-Fiqhiyyah Ma'a Al-Syarh Al-Mujaz" (Beirut-Lebanon: Dar At-Tirmidzi, 1989); Azizah, Al-Qawä’id Wa Ad-Dhawäbith Al-Fiqbiyyah Al-Mustakblashab Min Kitäb Ushül Al-Fatāya Li Al-Imām Ibnu Härits Al-Khusyni (Al-Jazairi: Jami'ah Al-Jazairi, 2001); Mani' bin Hammad Al-Juhni, Al-Mausü'ah AlMuyassarab Fì Al-Adyān Wa Al-Madzăhib Wa Al-Abžāb Al-Mu'āshirab (Maktabah Al-Mulk Fahd Al-Wathaniyyah, n.d.). 


\section{Kesimpulan}

Dalam dimensi modernitas dan globalisasi disertai dengan kondisi global yang sedang ditimpa musibah pandemic Covid-19 diperlukan upaya-upaya inovatif dan kreatif yang harus dilakukan oleh para pegiat dakwah dalam rangka meningkatkan dorongan mahasiswa maupun generasi millennial pada umumnya untuk mengikuti kajian-kajian dakwah online saat ini. gerakan-gerakan aktivitas dakwah haruslah mulai mengadopsi kultur dan budaya yang diinginkan masyarakat modern hari ini. oleh sebab itu, pendekatan dakwah islamiyyah tidak cukup dengan mengandalkan cara-cara konvensional dan tradisional, namun harus lebih inovatif, dinamis, menarik dan kompetitif. Tantangan dakwah dalam dimensi modernitas dan globalisasi begitu besar, oleh sebabnya upaya-upaya praktis dalam rangka meningkatkan minat para mahasiswa adalah lebih kreatif dalam membuat konten dakwah, tema harus lebih diprioritaskan kisah-kisah inspiratif dan memotivasi, memaksimalkan penggunaan media, pengemasan pesan dakwah harus baik, materi harus disesuaikan dengan kadar intelektualitas, gaya komunikasi jangan monoton, serta menanamkan nilai-nilai religiusitas. Proses optimalisasi dakwah online akan berkorelasi dengan kemajuan peradaban umat islam dimasa yang akan datang, oleh sebabnya perhatian serius harus betul-betul dilakukan sedini mungkin agar hasilnya lebih optimal.

\section{Daftar Pustaka}

Abiad, Abdul, Mia Arao, Suzette Dagli, Benno Ferrarini, Ilan Noy, Patrick Osewe, Jesson Pagaduan, Donghyung Park, and Reizle Platitas. "The Economic Impact of the COVID-19 Outbreak on Developing Asia." ADB Briefs 3, no. 128 (2020): 1-13. http://dx.doi.org/10.22617/BRF200096.

Ahmad, Attiya. "Explanation Is Not the Point: Domestic Work, Islamic Dawa and Becoming Muslim in Kuwait." Asia Pacific Journal of Anthropology 11, no. 3 (2010): 293-310.

Al-Arefe, Muhammad bin Abdurrahman. Istamti' Bi Hayātika Funūn At-Ta'āmul Ma'a An-Nās Fì Drilli As-Sìrah An-Nabawiyyah. Saudi Arabia: Sarikah Muslim: Saudi Arabia: Sarikah Muslim, 2011.

Al-Būṭī, Muḥammad Sacīd Ramaḍān. "Dhawabith Al-Mashlahah Fi Al-Sya'riah AlIslamiyyah.” Damaskus: Muassasah Ar-Risalah, 1973.

Al-Da'as, Izat 'Ubayd. “Al-Qawa'id Al-Fiqhiyyah Ma'a Al-Syarh Al-Mujaz.” BeirutLebanon: Dar At-Tirmidzi, 1989.

Al-Dirasah, Markaz Al-Buhuts wa. Fiqh Al-Wafäq. Maktabah Al-Mulk Fahd AlWathaniyyah: Maktabah Al-Mulk Fahd Al-Wathaniyyah, 2012.

Al-Juhni, Mani' bin Hammad. Al-Mausü'ah Al-Muyassarah Fì Al-Adyān Wa AlMadzāhib Wa Al-Ahz̄āb Al-Mu'äshirah. Maktabah Al-Mulk Fahd AlWathaniyyah, n.d.

Al-Laham, Alauddin Ibnu. "Al-Qawā’id Wa Al-Fawāid Al-Ushūliyyah Wa Mā Yata'allaq Bihā Min Al-Ahkām Al-Far'iyyah.” Kairo Mesir: As-Sunnah AlMuhammadiyyah, 1956.

Al-Qardhawi, Yusuf. Al-Ijtihäd F̄̄ As-Syarìah Al-Islämiyyah. Cairo: Dar Al-Qalam, 
1996.

. Fiqh Al-Wasathiyyah Al-Islämiyyah Wa At-Tajdìd Ma'ālimu Wa Manārātu. Cairo: Maktabah Wahbah, 2009.

—. Fiqh Al-Wasathiyyah Al-Islämiyyah Wa At-Tajdìd Ma'älimu Wa Manārätu. Mesir Kairo: Cairo: Maktabah Wahbah, 2009. https://www.alqaradawi.net/node/5066.

—. Syarìatu Al-Islämiyyah Shälihatun Lil Tathbìq Fì Kulli Zamān Wa Makān. Mesir Kairo: Cairo: Dar As-Shahwah Lil Nasyr Wa Tauji', 1993.

—. Ushūl Al-'Amal Al-Khairì Fì Al-Islām Fì Dhaui An-Nushūsh Wa Al-Maqāsid As-Syariah. Mesir Kairo: Cairo: Dar As-Syuruq, 2007.

Albarello, Fabrizio, Elisa Pianura, Federica Di Stefano, Massimo Cristofaro, Ada Petrone, Luisa Marchioni, Claudia Palazzolo, et al. "2019-Novel Coronavirus Severe Adult Respiratory Distress Syndrome in Two Cases in Italy: An Uncommon Radiological Presentation.” International Journal of Infectious Diseases 93 (2020): 192-197.

Andrew, Merrindahl. "Women's Electoral Lobby on the Continuum of Radicalism” 29, no. 82 (2015): 366-377.

Arai, Kazuhiro. "Combining Innovation and Emotion in the Modernization of Sufi Orders in Contemporary Egypt." Critique: Critical Middle Eastern Studies 16, no. 2 (2007): 155-169.

As-Sya'rawi, Muhamad Mutawalli. “Al-Ghaib.” Kairo Mesir: Maktabah Al-Sya'rawi Al-Islamiyyah, 1998.

At-Tharīqī, Abdullah bin Ibrāhīm. "Fiqh At-Ta'āmul Ma'a Al-Mukhālif." Riyadh Saudi Arabia: Dar Al-Wathan, 2010.

Azizah. Al-Qawāìd Wa Ad-Dhawābith Al-Fiqhiyyah Al-Mustakblashah Min Kitāb Ushūl Al-Fatāya Li Al-Imām Ibnu Hārits Al-Khusyni. Al-Jazairi: Jami’ah Al-Jazairi, 2001.

Bräuchler, B. "Cyberidentities at War: Religion, Identity, and the Internet in the Moluccan Con- Flict.” Indonesia 75 (2003): 123-151.

Bruner, Robert F., and Juliane Iannarelli. "Globalization of Management Education.” Journal of Teaching in International Business 22, no. 4 (2011): 232-242.

Buhle, Paul. "Toward the Understanding of the Visual Vernacular: Radicalism in Comics and Cartoons." Rethinking Marxism 18, no. 3 (2006): 367-381.

Bungin, M Burhan. "Masyarakat Indonesia Kontemporer Dalam Pusaran Komunikasi." Jurnal Komunikasi Pembangunan 1, no. 2 (2011): 125-136. http://jurnalaspikom.org/index.php/aspikom/issue/download/6/3.

Chaplin, Chris. "Salafi Activism and the Promotion of a Modern Muslim Identity: Evolving Mediums of Da'wa amongst Yogyakartan University Students." South East Asia Research 26, no. 1 (2018): 3-20.

Crawford, M. J. "The Da 'wa of Ibn 'Abd Al-Wahhāb before the Al Sa 'ūd." Journal of Arabian Studies 1, no. 2 (2011): 147-161.

Dang, Christine Thu Nhi. "Erotics, Poetics, Politics: The Spheres of Action of Senegalese Sufi Voices." Ethnomusicology Forum 26, no. 3 (2017): 349-372.

Degorge, Barbara. "Millennial Islam in Africa: Sufi Politics in the Sudan." The European Legacy 5, no. 2 (2000): 195-206.

Fahri, Mohamad, and Ahmad Zainuri. "Moderasi Beragama Di Indonesia." Intizar 
25, no. 2 (2019): 95-100.

Fedotova, Olga. "Radicalism and Terrorism Problems in a Scientific Discourse of Russian Social Sciences." Procedia - Social and Behavioral Sciences 92 (2013): 334 343.

Fife, Eric M., Leigh C. Nelson, and Amber S. Messersmith. "The Influence of Family Communication Patterns on Religious Orientation Among College Students." Journal of Family Communication 14, no. 1 (2014): 72-84.

Gillen Hoke, Hailey. "Sensitive Issues, Religion, and Respect in the Gender and Communication Course." First Amendment Studies 52, no. 1-2 (2018): 114-125. https://doi.org/10.1080/21689725.2018.1511442.

Goodwin, A. Lin. "Globalization, Global Mindsets and Teacher Education." Action in Teacher Education 42, no. 1 (2020): 6-18. https://doi.org/10.1080/01626620.2019.1700848.

GULAY, EROL N. "The Gülen Phenomenon: A Neo-Sufi Challenge to Turkey's Rival Elite?” Critique: Critical Middle Eastern Studies 16, no. 1 (2007): 37-61.

Ham, Jessica R. "Cooking to Be Modern but Eating to Be Healthy: The Role of Dawa-Dawa in Contemporary Ghanaian Foodways." Food, Culture and Society 20, no. 2 (2017): 237-256. http://dx.doi.org/10.1080/15528014.2017.1305827.

Haron, Muhammed. "Da'wah Movements and Sufi Tariqahs: Competing for Spiritual Spaces in Contemporary South(Ern) Africa ." Journal of Muslim Minority Affairs 25, no. 2 (2005): 261-285.

Hew, Wai Weng. "THE ART OF DAKWAH: Social Media, Visual Persuasion and the Islamist Propagation of Felix Siauw." Indonesia and the Malay World 46, no. 134 (2018): 61-79.

Hirschkind, C. The Ethical Soundscape: Cassette Sermons and Islamic Counterpublics. New York: Columbia University Press, 2009.

Hui, J Y. "The Internet in Indonesia: Development and Impact of Radical Websites." Studies in Conflict \& Terrorism 33, no. 2 (2010): 171-191.

Imron, Ali. "Pendidikan Kepribadian Anak Menurut Abdullah Nashih Ulwan." Edukasia Islamika 1, no. 1 (2016): 89-118.

Jiwa, Shainool. "The Genesis of Ismā'̄̄lI Da'Wa Activities in the Yemen." British Society for Middle Eastern Studies. Bulletin 15, no. 1-2 (1988): 50-63.

Josefsson, Tommy, Marco Nilsson, and Klas Borell. "Muslims Opposing Violent Radicalism and Extremism: Strategies of Swedish Sufi Communities." Journal of Muslim Minority Affairs 37, no. 2 (2017): 183-195. https://doi.org/10.1080/13602004.2017.1339498.

Kinkead-Clark, Zoyah. "Early Childhood Care and Education in Jamaica. Stakeholders' Perceptions of Global Influences on a Local Space.” Early Child Development and Care 187, no. 10 (2017): 1484-1495.

Laffan, Michael. "The Makings of Indonesian Islam: Orientalism and the Narration of a Sufi Past." The Makings of Indonesian Islam: Orientalism and the Narration of a Sufi Past 19, no. 5 (2011): 1 1-301. http://dx.doi.org/10.1080/10848770.2014.943520.

Lengauer, Dayana. "Sharing Semangat Taqwa: Social Media and Digital Islamic Socialities in Bandung." Indonesia and the Malay World 46, no. 134 (2018): 5-23. 
Lin, Qianying, Shi Zhao, Daozhou Gao, Yijun Lou, Shu Yang, Salihu S. Musa, Maggie H. Wang, et al. "A Conceptual Model for the Coronavirus Disease 2019 (COVID-19) Outbreak in Wuhan, China with Individual Reaction and Governmental Action.” International Journal of Infectious Diseases 93 (2020): 211216. https://doi.org/10.1016/j.ijid.2020.02.058.

Machingambi, Severino. "The Impact of Globalisation on Higher Education: A Marxist Critique.” Journal of Sociology and Social Anthropology 5, no. 2 (2014): 207215.

Malawi, Ibadullah. "Implementasi Pendidikan Karakter Melalui Pembelajaran Dalam Mata Pelajaran Di Sekolah Dasar." Premiere Educandum: Jurnal Pendidikan Dasar dan Pembelajaran 3, no. 01 (2016): 1-12.

Martin, Vanessa. "Islamist Radicalism in the Provinces of Iran 1906-9: A Stage in the Development of Islamism." Middle Eastern Studies 53, no. 5 (2017): 687699. http://dx.doi.org/10.1080/00263206.2017.1288619.

Milani, Milad, and Vassilis Adrahtas. "Modern Talking: Sufi Socio-Political Discourse." Journal of Religious and Political Practice 4, no. 2 (2018): 175-194. https://doi.org/10.1080/20566093.2018.1439813.

Mouser, Audrey E. 'Defining 'Modern' Malay Womanhood and the Coexistent Messages of the Veil." Religion 37, no. 2 (2007): 164-174.

MOWLANA, HAMID. "Communication, Philosophy and Religion." Journal of International Communication 9, no. 1 (2003): 11-34.

Mucharomah, Miftah. "Pendidikan Karakter: Sebuah Visi Islam Rahmatan Lil Alamin." Edukasia Islamika 2, no. 2 (2017): 191-207.

Munir, Muhammad. "Fenomena Dakwah Online Dan Offline Ustadz Abdus Somad Di Pondok Pesantren Al-Amien Prenduan Sumenep Madura Pendahuluan Ketenteraman Dalam Kehidupan Masyarakat Merupakan Salah Satu Harapan Seluruh Masyarakat Didunia , Tidak Juga Masyarakat Yang Di Kehidupa." Islamic Management and Empowerment 1, no. 1 (2019): 129-142.

Nasir Muhammadi Muhammad Jad. “Al-Ta'amul Ma'a Ghayr Al-Muslimin Fi 'Ahd Al-Nabawi," 2009.

Nieto, Sonia. "Diversity, Globalization, and Education: What Do They Mean for Teachers and Teacher Educators?” Kappa Delta Pi Record 49, no. 3 (2013): 105107.

Nisa, Eva F. "Social Media and the Birth of an Islamic Social Movement: ODOJ (One Day One Juz) in Contemporary Indonesia." Indonesia and the Malay World 46, no. 134 (2018): 24-43.

Nugroho, Puspo. "Internalisasi Nilai-Nilai Karakter Dan Kepribadian Mahasiswa Pendidikan Agama Islam Melalui Pendekatan Humanis-Religius." Edukasia: Jurnal Penelitian Pendidikan Islam 12, no. 2 (2017): 355.

Nurhadi, Zikri Fachrul, and Achmad Wildan Kurniawan. "Kajian Tentang Efektivitas Pesan Dalam Komunikasi." Jurnal Komunikasi Hasil Pemikiran dan Penelitian 3, no. 1 (2017): 90-95.

Ramdan, Ahmad Yasar, and Puji Yanti Fauziah. "Peran Orang Tua Dan Guru Dalam Mengembangkan Nilai-Nilai Karakter Anak Usia Sekolah Dasar." Premiere Educandum: Jurnal Pendidikan Dasar dan Pembelajaran 9, no. 2 (2019): 
100.

Rawwas, Muhamad. "Dirasah Tahliliyyah Li Syahshiyati Ar-Rasul Muhammad." Lebanon Beirut: Dar An-Nafais, 1988.

Rehman, Uzma, and Peter Lund-Thomsen. "Social Support at a Sufi Lodge in Punjab, Pakistan.” Contemporary South Asia 22, no. 4 (2014): 377-388.

Rock, Aaron. "Amr Khaled: From Da'wa to Political and Religious Leadership." British Journal of Middle Eastern Studies 37, no. 1 (2010): 15-37.

Rytter, Mikkel. "Burger Jihad: Fatal Attractions at a Sufi Lodge in Pakistan." Journal of Muslim Minority Affairs 36, no. 1 (2016): 46-61.

Rywkin, Michael. "The Communist Party and the Sufi Tariqat in the ChechenoIngush Republic.” Central Asian Survey 10, no. 1-2 (1991): 133-145.

Salvatore, Armando. "Sufi Articulations of Civility, Globality, and Sovereignty." Journal of Religious and Political Practice 4, no. 2 (2018): 156-174. https://doi.org/10.1080/20566093.2018.1439808.

Schofield, Philip. "Jeremy Bentham, the French Revolution and Political Radicalism.” History of European Ideas 30, no. 4 SPEC.ISS. (2004): 381-401.

Shanahan, Rodger. "Shi a Political Development in Iraq: The Case of the Islamic Da Wa Party." Third World Quarterly 25, no. 5 (2004): 943-954.

Soyusiawaty, Dewi. "Strategi Humas Dalam Menjalin Good Relationship Dengan External Stakeholders UAD.” Komuniti: Jurnal Komunikasi dan Teknologi Informasi 8, no. 2 (2016): 102-110.

Stark, Jan. 'Beyond 'terrorism' and 'State Hegemony': Assessing the Islamist Mainstream in Egypt and Malaysia." Third World Quarterly 26, no. 2 (2005): 307-327.

Stjernholm, Simon. "Sufi Politics in Britain: The Sufi Muslim Council and the 'Silent Majority' of Muslims." Journal of Islamic Law and Culture 12, no. 3 (2010): 215226.

Suryahadi, Asep, Ridho Al Izzati, and Daniel Suryadarma. "Estimating the Impact of Covid-19 on Poverty in Indonesia." Bulletin of Indonesian Economic Studies 56, no. 2 (2020): 175-192.

Syadi, Khalid Abu. Bi Ayyi Qalb Nalqahu. Mesir: Al-Andalus Al-Jadidah Li AnNasyri Wa At-Tauzi, 2008.

Tight, Malcolm. "Globalization and Internationalization as Frameworks for Higher Education Research." Research Papers in Education 36, no. 1 (2021): 52-74. https://doi.org/10.1080/02671522.2019.1633560.

Watson, Keith. "The Impact of Globalization on Educational Reform and Language Policy: Some Comparative Insights from Transitional Societies." Asia Pacific Journal of Education 21, no. 2 (2001): 1-18.

Weismann, Itzchak. "Between Da'wa and Dialogue: Religious Engagement in Muslim-Minority Environments.” Islam and Christian-Muslim Relations 30, no. 4 (2019): 505-522. https://doi.org/10.1080/09596410.2019.1601909.

Weldon, Peter A., Jevdet Rexhepi, Chen Wei Chang, Lauren Jones, Lucas Arribas Layton, Amy Liu, Susan Mckibben, et al. "Globalization and Higher Education in Southern California: Views from the Professoriate." Compare 41, no. 1 (2011): 5-24.

Wiktorowicz, Q. The Management of Islamic Activism; Salafis, the Muslim Brotherhood, and 
22 Jurnal Dakwah dan Komunikasi, Vol.6 No.1, 2021

State Power in Jordan. New York: State University of New York, 2001.

Yusof, Kamaruzaman, Iran Herman, and Badlihisham Mohd Nasir. "Islamic Radicalism in Malaysia: Gender Perspective." Procedia - Social and Behavioral Sciences 5 (2010): 2119-2125. 